\title{
PENGARUH DUKUNGAN KELUARGA TERHADAP TINGKAT DEPRESI PADA LANJUT USIA DI DAERAH ISTIMEWA YOGYAKARTA
}

\author{
The Influence Of Family Support On Depression Levels \\ Of Elderly In Yogyakarta
}

\author{
Aini Inayati ${ }^{1}$, Dwiky Imam Ichsani ${ }^{2}$ \\ ${ }^{1}$ Fakultas Ilmu Kesehatan Universitas Alama Ata Yogyakarta \\ ${ }^{2}$ Asri Medical Center \\ ainiinayati10@gmail.com
}

\begin{abstract}
ABSTRAK
Background: Usia lanjut adalah tahap akhir dari siklus hidup manusia, dewasa ini gangguan depresi pada lanjut usia merupakan interaksi faktor biologik, psikologik dan sosial. Faktor sosial adalah berkurangnya interaksi sosial, kesepian, berkabung dan kemiskinan dapat mencetuskan depresi. Tujuan: Untuk mengetahui pengaruh dukungan keluarga terhadap tingkat depresi pada lansia di Yogyakarta Metode: Pada penelitian ini menggunakan desain penelitian kuantitatif dengan pendekataan cross sectional. Sampel yang digunakan berjumlah 97 lanjut usia yang memenuhi kriteria inkulsi dan eksklusi. Pengambilan sampel pada penelitian ini menggunakan purposive sampling dengan analisa data menggunakan SPSS 17.0. Hasil: Hasil uji Rank Spearman diperoleh nilai signifikansi (2-tailed) dengan hasil 0.001 yang berarti $0.001<0.05$, maka $\mathrm{H}_{1}$ diterima artinya ada hubungan yang signifikan antara dukungan keluarga terhadap tingkat depresi pada lansia di Nganglik kabupaten Sleman Yogyakarta. Sedangkan tingkat depresi pada lansia didapatkan depresi ringan 18.6\% (18 responen), depresi sedang sebanyak 78.4\% (76 responden) dan depresi berat sebanyak 3.1\% (3 responden). Kesimpulan: Dukungan keluarga sangat bermanfaat dalam pengendalian depresi lansia dan dapat pula mengurangi tekanan-tekanan yang ada pada konflik yang terjadi pada diri lansia. Dukungan keluarga berkaitan dengan pembentukan keseimbangan mental dan kepuasan psikologis. Dukungan didapatkan dari keluraga yang terdiri dari suami atau istri, anak, cucu, saudara, ataupun keluarga dekat lansia.
\end{abstract}

Kata Kunci: Dukungan Keluarga, Depresi, Lansia

\begin{abstract}
Background: The elderly is the final stage of the human life cycle, today the depression in elderly is an interaction of biological, psychological and social factors. Social factors are decreasing social interaction, loneliness, mourning and poverty can trigger depression. Objective: To determine the effect of family support on the level of depression in elderly in Yogyakarta Method: This study used quantitative research design with cross sectional approach. The sample used was 97 elderly who met the criteria for inclusion and exclusion. Sampling in this study used purposive sampling with data analysis using SPSS 17.0. Results: The results of
\end{abstract}


the Spearman Rank test obtained a significance value (2-tailed) with a result of 0.001 which means $0.001<0.05$, then $\mathrm{H} 1$ is accepted meaning that there is a significant relationship between family support with the level of depression in elderly in Nganglik, Sleman, Yogyakarta. While the level of depression in elderly found mild depression $18.6 \%$ (18 responses), moderate depression as much as $78.4 \%$ (76 respondents) and major depression as much as $3.1 \%$ (3 respondents).

Conclusion: Family support is very beneficial in controlling depression of the elderly and also reduce the pressures that exist in conflicts that occur in the elderly. Family support is related to the formation of mental balance and psychological satisfaction. Support is obtained from families consisting of husband or wife, children, grandchildren, siblings, or close relatives of the elderly.

Keyword: Family Support, Depression, Elderly

\section{PENDAHULUAN}

Secara umum insiden depresi menyerang 10 - 15\% lansia 65 tahun keatas yang tinggal dikeluarga dan angka depresi meningkat secara drastis pada lansia yang tinggal di institusi, dengan sekitar $50-75 \%$ penghuni perawatan jangka panjang memiliki gejala depresi ringan sampai sedang (Stanley \& Beare, 2007). Pada lansia, prevalensi depresi diperkirakan $15 \%$ dari populasi usia lanjut, dan diduga sekitar $60 \%$ dari pasien di unit geriatrik menderita depresi. Menurut The National Old People's Welfare Council di Inggris yang dikutip oleh Nugroho (2008) menyatakan bahwa depresi merupakan salah satu penyakit atau gangguan umum pada lansia yang menduduki ranking teratas. UndangUndang No. 13 tahun 1998 tentang kesejahteraan lanjut usia dikatakan bahwa yang dimaksud dengan lanjut usia adalah seseorang yang berusia 60 tahun keatas. Di Indonesia jumlah penduduk lanjut usia terus menerus meningkat.

Dari hasil survey awal yang di lakukan pada Juli 2018 terdapat 1.549 penduduk laki-laki dan 1.546 penduduk perempuan di kecamatan Nganglik Sleman, Yogyakarta masing-masing dibedakan menjadi tiga kategori yaitu; usia 65-69 tahun, 850 lansia laki-laki dan 996 lansia perempuan, sedangkan yang berusia 70-74 tahun terdapat 792 laki-laki dan 947 perempuan, sedangkan kategori $>75$ tahun terdapat 768 lansia laki-laki dan 927 lansia perempuan berdasarkan data dari ditjen kependudukan dan pencatatan sipil Daerah Istimewa Yogyakarta, 2018.

Sebagian besar lansia yang mengikuti kegiatan posyandu lansia tersebut ada yang mengalami gangguan pada pendengaran, penglihatan, gangguan dalam beraktifitas karena penyakit yang di deritanya, stres dan depresi yang disebabkan karena perasan tidak berguna, tidak produktif, kehilangan pasangan hidup, berada jauh dari anak, sehingga kurangnya perhatian diri baik dari orang lain maupun lingkungan dan berbagai penurunan atau kemunduran baik fungsi biologis maupun psikis. Penurunan fungsi biologis dan psikis ini mempengaruhi mobilitas dan juga kontak sosial. Menurunnya kontak sosial ini sering 
membawa lanjut usia kepada masalah depresi (Bandiah, 2004).

Saat ini gangguan depresi pada usia lanjut kurang dipahami sehingga banyak kasus depresi pada usia lanjut tidak dikenali dan tidak diobati. Terjadinya depresi pada usia lanjut merupakan interaksi faktor biologik, psikologik dan sosial. Faktor sosial adalah berkurangnya interaksi sosial, kesepian, berkabung dan kemiskinan dapat mencetuskan depresi. Sedangkan faktor psikologik yang berperan dalam timbulnya depresi adalah rasa rendah diri, kurang percaya diri, kurangnya rasa keakraban, dan ketidakberdayaan karena menderita penyakit kronis. Dari aspek biologis usia lanjut mengalami kehilangan dan kerusakan banyak sel-sel saraf maupun zat neurotransmiter, resiko genetik maupun adanya penyakit tertentu seperti kanker, diabetes mellitus, stroke memudahkan terjadinya gangguan depresi. Semua hal tersebut menuntut kemampuan beradaptasi yang cukup besar (Abednego, 2014).

Menurut Erikson (2007:369) tahap lansia sebagai tahap integrity versus despair yakni individu yang sukses melampaui tahap ini akan dapat beradaptasi dengan baik, menerima berbagai perubahan dengan tulus, mampu berdamai dengan keterbatasannya, bertambah bijak menyikapi kehidupan. Sebaliknya mereka yang gagal akan melewati tahap ini dengan penuh pemberontakan, putus asa dan ingkar terhadap kenyataan yang dihadapinya. Sukses tidaknya seseorang melewati tahap ini dipengaruhi oleh maturitas kepribadian pada fase sebelumnya, tekanan hidup yang dihadapinya, dan dukungan dari lingkungan terdekatnya termasuk keluarga.

Dukungan sosial berasal dari lingkungan dapat diperoleh dari keluarga, maupun masyarakat yang mana mereka bersedia dan perduli dengan masalah-masalah yang dihadapi lansia. Dukungan keluarga merupakan salah satu bentuk dari terapi keluarga yang termasuk pada penatalaksanaan depresi pada usia lanjut, karena melalui keluarga berbagai masalah-masalah kesehatan itu bisa muncul sekaligus dapat diatasi. Adanya problem keluarga akan berpengaruh pada perkembangan depresi pada lansia. Disamping itu proses penuaan yang terjadi pada lansia juga dapat mempengaruhi dinamika keluarga. Melalui dukungan keluarga, lansia akan merasa masih ada yang memperhatikan, ikut merasakan mau membantu mengatasi beban hidupnya. Berdasarkan latar belakang di atas dan untuk memperoleh gambaran yang nyata tentang dukungan sosial keluarga terhadap depresi pada lansia, maka peneliti tertarik untuk melakukan penelitian Pengaruh Dukungan Keluarga Terhadap Tingkat Depresi pada Lansia Di Yogyakarta.

\section{METODE}

Pada penelitian ini menggunakan desain penelitian kuantitatif dengan pendekataan cross sectional yaitu suatu penelitian yang mempelajari dinamika korelasi antara faktor-faktor resiko dengan efek, dengan cara pendekatan, observasi atau pengumpulan data sekaligus pada suatu saat. Artinya tiap subjek penelitian hanya diobservasi sekali saja dan pengukuran dilakukan terhadap status karakter atau variable subjek pada saat pemeriksaan (Notoatmodjo, 2005:26). 
Instrument yang diguanakan adalah GDS dari D'Ata dalam APA, 2018. Untuk instrument dukungan kelurga menggunakan kuesioner self reportinformasiform yang disusun untuk mendapatkan informasi yang diharapkan dari responden sesuai dengan pertanyaan (Nursalam, 2008). Dalam penelitian ini penulis hanya ingin mengetahui bagaimana pengaruh dukungan keluarga terhadap tingkat depresi pada lansia

\section{HASIL PENELITIAN}

Pada data ini mengiterpretasikan karakteristik responden berdasarkan umur, pekerjaan, aktif mengikuti Posyandu, dan jenis kelamin.

\subsubsection{1 \\ Karakteristik}

berdasarkan umur

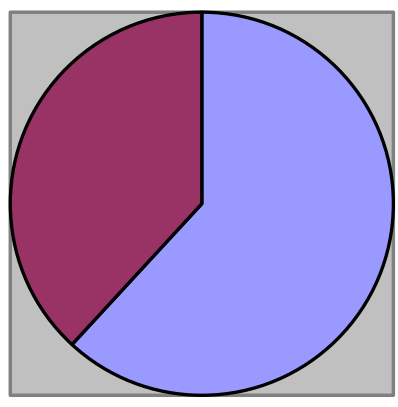

口usia 70-75

口usia $>75$

Gambar 4.1 Diagram pie distribusi frekuensi responden berdasarkan umur di kecamatan ngangklik, Sleman Yogyakarta.

Berdasarkan gambar 4.1 didapatkan umur responden hampir setengah lebih berusia $70-75$ tahun $28.1 \% \quad$ (37 responden). Sedangkan usia $>75$ tahun sebanyak (60 responden) $61.9 \%$.

4.1.2.2 Karakteristik responden berdasarkan pendidikan

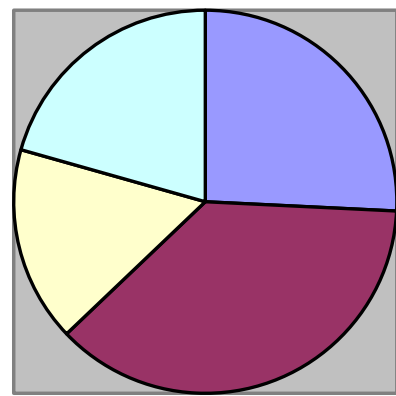

口Pensiun PNS

口IRT

$\square$ Buruh

口wasta

Gambar 4.2 Diagram pie distribusi frekuensi responden berdasarkan Pekerjaan di kecamatan ngangklik, Sleman Yogyakarta.

Dilihat dari gambar 4.2 pekerjaan responden yang tebanyak adalah IRT sebanyak 36 responden (36.1\%), selain IRT pekerjaan yang banyak pada responden adalah pensiunan PNS yaitu sebanyak 25 responden $(25.8 \%)$.

\subsubsection{Karakteristik lansia Mengikuti} Posyandu

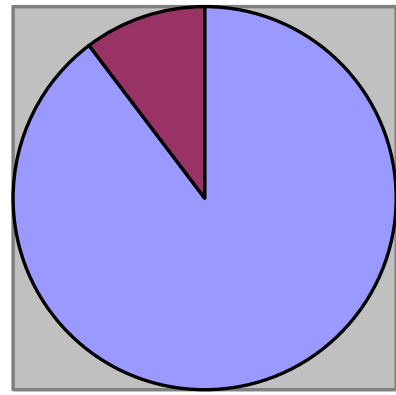

口ya

口tidak

Gambar 4.3 Diagram pie distribusi frekuensi responden berdasarkan pekerjaan di kecamatan ngangklik, Sleman Yogyakarta.

Berdasarkan gambar didapatkan 87 reponden tidak mengikuti posyandu lansia (89.7\%), dan yang mengikuti posyandu lansia terdapat 10 reponden $(10.3 \%)$.

4.1.2.4 Karakteristik responden 
berdasarkan jenis kelamin

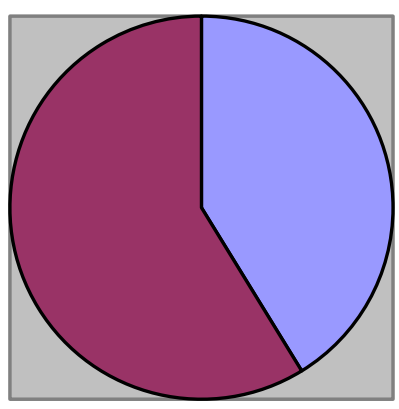

Diagram 4.4 Diagram pie distribusi frekuensi responden berdasarkan jenis kelamin di kecamatan ngangklik, Sleman Yogyakarta.

Berdasarkan gambar 4.4 didapatkan jenis kelamin responden sebagian besar perempuan $58.8 \%$ (57 responden) dan hampir setengah laki-laki $40.1 \% \quad$ (40 responden).

Pada data ini disajikan dalam bentuk table tentang dukungan keluarga dan Geriatric Depression Slace (GDS-15) serta analisa pengaruh dukungan keluarga terhadap tingkat depresi pada lansia yang berada di kecamatan ngangklik, Sleman Yogyakarta.

4.1.3.1 Karakteristik depresi lansia di kecamatan ngangklik, Sleman Yogyakarta. Tabel 4.1 Distribusi Depresi Lansia Di kecamatan Ngangklik, Sleman Yogyakarta.

\begin{tabular}{clcc}
\hline No & $\begin{array}{l}\text { Depresi } \\
\text { Lansia }\end{array}$ & Jumlah & Prosentase \\
\hline 1 & Depresi & 18 & $18.6 \%$ \\
2 & Ringan & 76 & $78.4 \%$ \\
3 & Depresi & 3 & $3.1 \%$ \\
& Sedang & & \\
& Depresi & & \\
& Berat & & \\
& Total & 97 & $100 \%$ \\
\hline
\end{tabular}

Berdasarkan tabel 4.1 Tigkat depresi pada lansia dari 97 responden didapatkan $18.6 \%$ (18 reponden) depresi ringan, 78,4\% (76 responden) depresi sedang, dan $3.1 \%$ (3 responden) mengalami depresi berat.

4.1.3.2 Karakteristik dukungan keluarga di kecamatan ngangklik, Sleman Yogyakarta.

Tabel 4.2 Distribusi Frekuensi Dukungan Keluarga di kecamatan ngangklik, Sleman Yogyakarta.

\begin{tabular}{llll}
\hline No & $\begin{array}{l}\text { Dukungan } \\
\text { Keluarga }\end{array}$ & Jumlah & Prosentase \\
\hline 1 & Dukungan & 3 & $3.1 \%$ \\
2 & Kurang & 18 & $18.6 \%$ \\
3 & Dukungan & 76 & $78.4 \%$ \\
& Sedang & & \\
& Dukungan & & \\
& Baik & & \\
& Total & 48 & $100 \%$ \\
\hline
\end{tabular}

Berdasarkan tabel 4.2 dukungan keluarga yang kurang tidak ada, sisanya sebagian besar sedang $18.6 \%$ (18 responden) dan baik $78,4 \%$ (76 responden).

4.1.3.3 Analisa karakteristik pengaruh dukungan keluarga terhadap tingkat depresi pada lansia kecamatan ngangklik, Sleman Yogyakarta.

Tabel 4.3 Cross tabulasi data pengaruh dukungan keluarga terhadap tingkat depresi pada lansia di Nganglik, Sleman Yogayakarta.

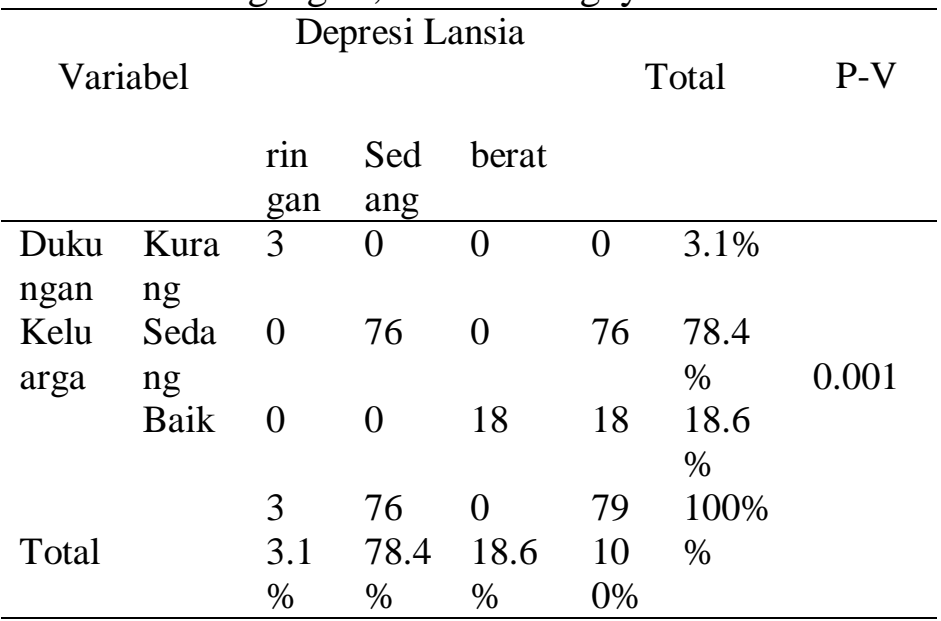


Berdasarkan tabel 4.3 nilai tabulasi didapatkan hasil bahwa dukungan keluarga yang sedang sebanyak $78.4 \%$ yaitu: 76 responden dari 97 responden, depresi lansia. Sedangkan dukungan keluarga yang kurang dan ringan $3.1 \%$ atau 3 responden. Dan sedangkan dukungan keluarga yang baik berat $18.6 \%$ yaitu 18 responden dari 97 responden.

Hasil analisa data dari veriabel independen dukungan keluarga yang dihubungkan dengan variable dependen tingkat depresi pada lansia berdasarkan uji Korelasi Spearman's Rank yang menggunakan komputer SPSS (Sofware Product and Service Solution) versi 17.0.

Berdasarkan hasil uji Rank Spearman diperoleh nilai signifikansi (2-tailed) dengan hasil 0,001 yang berarti $0,001<0,05$, maka HI diterima artinya ada hubungan yang signifikan antara dukungan keluarga terhadap tingkat depresi pada lansia di Nganglik kabupaten Sleman Yogyakarta. Hal ini menunjukan bahwa dukungan keluarga dapat mempengaruhi depresi lansia

\section{PEMBAHASAN}

Dilihat dari tabel Berdasarkan tabel 4.1 Depresi lansia didapatkan hasil, responden dengan depresi sedang sebanyak $78,4 \%$ (76 responden) dan berat sebanyak $3.1 \%$ (3 responden).

Berdasarkan hasil uji Rank Spearman diperoleh nilai signifikansi (2tailed) diperoleh hasil 0,001 yang berarti $0,001<0,05$, maka HI diterima artinya ada hubungan yang signifikan antara dukungan keluarga terhadap tingkat depresi pada lansia di Berdasarkan tabel 4.1 Depresi lansia didapatkan hasil, responden dengan depresi sedang sebanyak 78,4\% (76 responden) dan berat sebanyak $3.1 \%$ (3 responden). Sehingga dukungan keluarga digunakan mengurangi depresi lansia tersebut karena dari hasil penelitian ini yang paling signifikan atau ada hubungan antara ke lima bentuk dukungan keluarga, namun sedikit rendah tetapi ada hubungan. Sekian dari populasi banyak yang kurang memahami akan dukungan keluarga dan depresi lansia sehingga penanganan depresi dan dukungan yang kurang optimal.

Sumber dukungan keluarga merupakan aspek yang paling penting untuk diketahui dan dipahami, dengan pengetahuan dan pemahaman tersebut seseorang akan tahu pada siapa ia akan mendapatkan dukungan sesuai dengan keinginannya. Sehingga dukungan tersebut memiliki makna yang sangat berarti bagi kedua belah pihak yakni keluarga dan lansia (Zainuddin, 2002). Helping Skills for Loss and Crisis (2008) dukungan bisa datang dari hubungan itu sendiri dimana lansia mengalami penerimaan dari keluarga dan kehangatan, mengarahkan bantuan konseling kedalam bentuk penentraman atau lingkungan yang mendukung, menentukan dan manajemen kritis.

Manusia adalah makhluk sosial yang tidak dapat hidup sendiri tanpa bantuan orang lain lebih spesifik lagi lansia selalu butuh dukungan dari orang lain terutama dukungan keluarga. Dukungan keluarga sangat bermanfaat dalam pengendalian depresi lansia dan dapat pula mengurangi tekanan-tekanan yang ada pada konflik yang terjadi pada diri lansia. Dukungan keluarga berkaitan dengan pembentukan keseimbangan mental dan kepuasan psikologis. Dukungan didapatkan dari keluraga yang terdiri dari suami atau istri, anak, cucu, saudara, ataupun keluarga dekat lansia.

\section{KESIMPULAN}

Berdasarkan hasil penelitian yang telah dilakukan oleh peneliti dapat disimpulkan sebagai berikut:

1. Setelah dilakukan observasi melalui 
penelitian dukungan keluarga terhadap lansia didapatkan memiliki anggota keluarga lansia yang bisa memberikan dukungan keluarga cukup baik

2. Tingkat depresi pada lanjut usia mayoritas didapatkan dari responden dalam kriteria sedang dan kriteria berat.

3. Ada pengaruh dukungan keluarga terhadap tingkat depresi pada lansia di Ngangklik, kabupaten Sleman Yogyakarta.

\section{SARAN}

Diharapkan petuagas kesehatan (para kader posyandu lansia, bidan desa dan petugas kesehatan puskesmas dan Rumah sakit) ikut serta memotivasi lansia agar aktif dalam kegiatan serta memotivasi keluarga untuk memberikan dukungan secara emosional maupun moril terhadap lanjut usia, sehingga tidak terjadi depresi pada lanjut usia yang memiliki keluarga ataupun yang tidak memiliki keluarga.

\section{DAFTAR PUSTAKA}

Abednego, Bangun. (2014). Sehat dan Bugar Hingga Lansia.Bandung : Indonesia Publishing House.

Ali, Zainuddin, 2000. Metode penelitian hukum. Jakarta :Sinar Grafik.

Bandiyah, Siti. (2009). Lanjut Usia dan Keperawatan Gerontik. Yogyakarta : Nuha Medika.

D’Ath, P, Katona, P, Mullan, E, Evans, S, \& Katona, C (1994). Screening, detection and management of depression in elderly primary care attenders, 1: The acceptability and performance of the 15-item GDS (GDS-15) and development of a shorter version. Family Practice, $11,260-266$

Erikson, Erick, H.1968. Identity, Youth, and Crisis. International University Press. New York. Erikson, Erick, H. 1989.Identitas dan Siklus Hidup Manusia; Bunga Rampai 1. Penerjemah : Agus Cremers. Jakarta : PT. Gramedia.

Notoadmodjo, Soekidjo. 2012. Metodologi penelitian kesehatan. Jakarta : Rineka Cipta.

Nugroho. 2000. Keperawatan Komunitas . Jakarta : Salemba Medika Notoadmodjo. 2006. Metodologi Penelitia Ed Revisi. Jakarta : Rineka Cipta.

Nugroho.(2008). Keperawatan Gerontik. Jakarta. Penerbit Buku Kedokteran : EGC

Nursalam.(2008). Konsep dan Penerapan Metodologi Penelitian Ilmu Keperawatan.Jakarta : Salemba Medika

Stanley, M \& Beare, PG. (2007).Buku Ajar Keperawatan Gerontik.Jakarta : EGC 